\title{
sciendo
}

\section{Evaluation of the level of corporate social responsibility of Ukrainian nuclear energy producers}

\author{
Olena GRISHNOVA \\ Taras Shevchenko National University of Kyiv, Ukraine \\ grishnova@ukr.net \\ Kateryna BEREZIUK \\ Institute of Industrial Economics, National Academy of Sciences of Ukraine, Kyiv, Ukraine \\ kateryna.bereziuk@gmail.com \\ Yuriy BILAN \\ Tomas Bata University of Zlin, Czech Republic; Sumy State University, Ukraine \\ y.bilan@prz.edu.pl
}

\begin{abstract}
The paper considers the role of the development of corporate social responsibility of Ukrainian nuclear energy producers to ensure the effective functioning of this industry. National sustainable development in all social and economic spheres depends heavily on effective employee management where safety plays the main role. The purpose of the article is to evaluate the development of corporate social responsibility in NNEGC "Energoatom" and identify reserves for improving enterprise employee management. To achieve this goal, the method of SPACE analysis has been modified, because this tool is traditionally used as a method of strategic management. A system of 23 indicators has been developed to evaluate the level of corporate social responsibility in NNEGC Energoatom. Four groups of factors were identified, each of them was assessed by a set of relevant indicators. The article covers the activities of the enterprise during 2016-2020. On the basis of mathematical calculations, the SPACE-analysis matrix is constructed and the strategy of corporate social responsibility development is defined. The evaluation of the level of corporate social responsibility in NNEGC Energoatom indicates a high level of CSR. Despite the effective corporate social responsibility policy in NNEGC Energoatom, some problems still exist. The analysis allowed identifying the ways to improve the corporate social responsibility of nuclear energy producers, particularly to ensure a competitive salary, increase the level of occupational safety, improve the internal communication system. The practical value of the analysis lies in the fact that the modified method of SPACE- analysis can be used to evaluate the corporate social responsibility in different types of enterprises with different aims and objectives.
\end{abstract}

Keywords: corporate social responsibility (CSR), CSR evaluation, nuclear energy, SPACE-analysis, employee management, stakeholders, employee motivation.

Please cite the article as follows: Grishnova, O., Bereziuk, K., Bilan, Y., (2021), "Evaluation of the level of corporate social responsibility of Ukrainian nuclear energy producers", Management \& Marketing. Challenges for the Knowledge Society, Vol. 16, No. 2, pp. 152-166, DOI: 10.2478/mmcks-2021-0010.

\section{Introduction}

Nuclear power still plays an important role in electricity production today. It is the secondlargest source of low-carbon electricity. Around $10 \%$ of the world electricity is generated by about 440 nuclear reactors. About 50 reactors are still under construction, which equals to approximately 15\% of existing capacity (World Nuclear Association, 2020).

DOI: $10.2478 / \mathrm{mmcks}-2021-0010$ 
In Ukraine, nuclear energy is produced by the State Enterprise "National Nuclear Energy Generating Company "Energoatom". The Company operates four nuclear power plants with 15 power units (NNEC “Energoatom", 2020).

It is difficult to overestimate the role of nuclear energy in the stability of the Ukrainian economy. In addition to the existing intersectoral relationships and their economic impact, responsible employee management in nuclear energy sector determines safety in all socioeconomic processes.

Violation of the balance of stakeholders' interests can have dangerous consequences in their various manifestations: the outflow of qualified personnel with unique functional skills, reduced safety, and consequent deterioration of general safety and comfort. Macroeconomic implications of this process have already been discussed in scientific works of Grishnova (Grishnova, 2014) and many others. Energoatom covers approximately 55\% of the electricity needs in Ukraine. In autumn-winter period, this figure reaches $70 \%$. However, the industry is experiencing significant changes today. And one of the factors in the development of the industry is to ensure a high level of social responsibility.

The development of the Ukrainian economy and European integration processes make enterprises redistribute priorities towards compliance with the principles of corporate social responsibility. At the same time, the opportunities for economic growth through the use of human potential are intensified (Dima \& Ghinea, 2016). The past experience of Chernobyl disaster puts a lot of pressure on CSR of nuclear energy producers. Nuclear energy is among economy sectors with low responsibility level such as alcohol, tobacco, gambling and weapons (Grougiou et al., 2016), (Lindorff et al., 2012). These industries are often described as "sins" due to their perceived deviation from broadly-endorsed understandings of value-to-society (Cai et al., 2012), (Devers et al, 2019).

Methodological issues related to the assessment of CSR are studied by many scientists (Pisani et al, 2017), (Husted \& Allen, 2009, 2011), (Kolk \& Tulder, 2010), (Khlevytska, 2014), (Crane et al., 2014), (Mishchuk \& Grishnova, 2015) (Chena et al., 2019), (Oliveira, at al., 2019). However, only few deals with CSR issues of nuclear energy producers (Mizuo, 2008), (Banerjee \& Bonnefous, 2011), (Kato et al., 2013), (Truelove \& Greenberg, 2013) (Simoncic, 2019), (Simoncic \& Zurga, 2016, 2019), though this stigmatized sector requires special attention. In addition, the urgency of assessing the CSR level is due to the need to address the challenges of strengthening Ukraine's competitive position in the international economic system. Evaluation of CSR level of in NNEGC Energoatom will allow identifying potential areas for improvement and formulating prospects and strategies of CSR development.

Therefore, the purpose of the paper is to analyze and evaluate the CSR level of nuclear energy producers in Ukraine by applying the SPACE-analysis and determine, on this basis, the priority areas of CSR development in nuclear energy sector of Ukraine.

The rest of the article is structured in the following way: section 1 presents literature review on the subject; section 2 introduces methods and data; section 3 discusses results and section 4 concludes.

\section{Literature review}

Currently energy sector is facing a lot of challenges concerned with sustainable development. Though there are strict legal regulations in this sector especially nuclear energy there are other important issues which are strongly depend on the related stakeholders, level of the transparency, market liberalization, restructuring and competition in energy sector (Streimikiene, et al., 2009), (Stjepcevic et al., 2017), (Lu et al., 2019). The corruption is one of the biggest problems linked to energy sector having negative impact on all other issues of sustainability of energy sector (Rimsaite, 2019). This is related with the political contestation and high impact of energy companies on economy (Hegerty, 2019), (Spence, 2011), 
(Tvaronavičienè et al., 2018), including indirect impact due to effectiveness of related municipal companies (Yakymova \& Kuz, 2019).

In addition, energy sector is not fully liberalized in most countries and partially owned by the state (Kolk, 2016). The renewable energy sector is especially vulnerable to corruption as publicly subsidized renewable energy sector is attractive for criminal associations between business and politicians having power on issue of licenses and control over public subsidies to renewables (Gennaioli \& Tavioni, 2016).

Another issue is nuclear energy. The former accidents in nuclear industry, like Chernobyldisaster (Lindell \& Perry, 1990) and Fukushima fallout in Japan (Shadrina, 2012) has significant impact on nuclear energy development and public perception about nuclear energy technologies therefore this sector is stigmatized.

The term stigma has been widely applied to organizations. The construct of organizational stigma and a general theory that explains the conditions under which organizational stigmas are likely to arise, how this process unfolds, and the initial effects stigmas inflict on organizations are provided by Devers et al. (2009). The roles, social context, social processes, and social actors that play the main role in the origination and effects of an organizational stigma were provided.

The nuclear energy industry continuously needs to safeguard its license to operate or run the risk of having its operations shut down due to public pressure due to stigmatization. Implementing corporate social responsibility (CSR) initiatives can allow nuclear energy organizations to get license to work under social pressure. But some authors argue that for firms in stigmatized industries it appears that core CSR actually limits managers in their ability to engage with stakeholders and achieve mutually beneficial outcomes. Lindorff et al. (2012) analyzed CSR in stigmatized industries and found that it must be conceptualized differently from the mainstream industries. However, some scholars (Husted \& Allen, 2009, 2011), (Yates \& Hollensbe, 2013) suggested that CSR are commendable in stigmatized industries CSR resolves conflicting tensions and increase business and societal value in highly contested settings (Crane et al., 2014), (Hahn et al., 2010), (Winn et al., 2012) which are valuable outcomes complementing positive influence of CSR on financial performance of the company (Myšková \& Hájek, 2019). Important issue stressed by scholars is fact that nuclear safety is related with high safety culture standards and the fulfilment of social responsibilities. Understanding of the CSR of NPPs includes sustainable functioning and is based on safety culture as the highest value and behavioral pattern of operators and owners (Simonci \& Zurga, 2016; 2019; Dima et al., 2019).

CSR in nuclear energy sector is closely linked to the respect for ethical and moral principles, and considers the interests of stakeholders from wider society (Hahn et al., 2010). An important condition for nuclear energy producers acceptance by society is trust that nuclear energy producers can create through public relations, good business results, stable and safe operations, the respect for international norms, ethical principles and regulatory obligations (Yates \& Hollensbe, 2013), (Goodfellow et al., 2015).

Based on analysis of scientific literature and revealed the importance of CSR in nuclear energy sector the first attempt to assess CSR level in National Nuclear Energy Generating Company of Ukraine NNEGC "Energoatom" operating nuclear power plants in Ukraine by applying SPACE model strategic analysis is performed.

\section{Methods and data}

SPACE - analysis is used mainly as a method of strategic analysis. The SPACE model is a developed version of the BCG (Boston Consulting Group) matrix. This model includes two internal (Financial strength - FS and Competitive advantage - CA) and two external dimensions (Environmental stability - ES and Industry strength - IS) (Borocki et al., 2018). SPACE method (evaluation of strategic assessment of actions) is a comprehensive method for analysis of the 
position in the market and choosing the optimal strategy for medium and small enterprises (Rudnicki \& Vagner, 2014). The method of SPACE-analysis can be an effective tool for assessing the internal social responsibility of enterprises. However, this method needs to be modified. We adapted traditional groups of factors for internal responsibility and identified six areas of assessment: remuneration and staff motivation, safety and working conditions, staff development, comprehensive employee benefits package, corporate culture, supporting young professionals. Each direction consists of indicators and corresponding coefficients. Coefficients are determined expertly in accordance with the importance of the indicator for employees.

To assess these factors of corporate social responsibility, we used a rating scale from 0 (minimum rating) to 3 (maximum rating).

Grade "0" reflects the lowest level of social responsibility by metric. It is envisaged in such cases: the absence of this direction of social policy, indicators below the average, policy is not complying with the law.

Grade "1" reflects the initial level of social responsibility in the enterprise, assigned in cases where this area is just beginning to develop.

Grade "2" (average level of social responsibility) corresponds to the average indicators of the energy sector, international standards and national legislation.

Grade "3" - high level of social responsibility. It is assigned in cases when the enterprise has advantages in comparison with other industrial enterprises. This area is strategically important for the enterprise. Indicators are higher than the industry average, as well as not lower than international standards.

Evaluation is based on comparative analysis and calculation of indicators.

Each of the factors corresponds to the weighted values on the basis of which the matrix is built After that, a quadrilateral is constructed, which reflects the values of each group of factors.

The matrix evaluates the indicators, which are grouped into four groups, defined by the classical method of SPACE-analysis: of financial stability of the enterprise; factors of functional safety of the enterprise; factors of competitiveness of the enterprise; factors of enterprise attractiveness (table 1).

Table 1 Factors of the SPACE-analysis matrix for socially responsible evaluation

\begin{tabular}{|l|l|}
\hline \multicolumn{1}{|c|}{ Group of factors } & \multicolumn{1}{c|}{ Direction of evaluation } \\
\hline Factors of financial stability of the enterprise & Remuneration and staff motivation \\
\hline Factors of functional safety of the enterprise & Safety and working conditions \\
\hline \multirow{2}{*}{ Factors of competitiveness of the enterprise } & Staff development \\
\cline { 2 - 3 } & Comprehensive employee benefits package \\
\hline \multirow{2}{*}{ Factors of attractiveness of the enterprise } & Corporate culture \\
\cline { 2 - 2 } & Supporting young professionals \\
\hline
\end{tabular}

Source: Authors' own research

The results of the analysis are presented in the matrix form based on the reflection of four groups of factors. Next, calculate the total percentage of compliance with the maximum possible score. According to the classical method of SPACE-analysis we determine the optimal strategy for the enterprise. To do this, select a point in the coordinate system. We look for the coordinates of a point according to the following formulas:

$\mathrm{X}=\mathrm{FA}$ (Factors of attractiveness of the enterprise) - FC (Factors of competitiveness of the enterprise)

$\mathrm{y}=\mathrm{FF}$ (Factors of financial stability of the enterprise) - FS (Factors of functional safety of the enterprise)

Depending on in what quarter the line will lie, we choose strategy of internal social responsibility development: aggressive, competitive, defensive, conservative (Borocki et al., 2018). 
Depending on the chosen strategy, it is possible to allocate the weakest issues of internal social responsibility of the enterprise.

Aggressive position means that particular attention should be paid to safety and working conditions; staff development; social package for staff.

Competitive position - means that particular attention should be paid to staff payment, staff motivation; staff development; social package for staff.

Defensive position - means that particular attention should be paid to staff payment and motivation; adaptation of young professionals and corporate culture.

Conservative position requires special attention to support young professionals; corporate culture; safety and working conditions.

Based on the identified "weaknesses" system of measures are formed to enhance internal social responsibility of the enterprise.

We conducted the expert survey to assess the level of corporate social responsibility. We used the following criteria to selecting experts:

$\checkmark$ practical experience related to nuclear energy - at least five years;

appropriate education - not less than higher;

$\checkmark$ understanding of social responsibility issues;

$\checkmark$ presentation of various areas of nuclear energy research.

12 experts from different fields were interviewed (consultants of Energy Supplier's Association, KPMG, European-Ukrainian Energy agencies, specialist of the NKREKP, analysts of Dixi group, scientists, NPP managers). Work experience of experts - 5-24 years. All experts has higher education. Three of them received a PhD degree, two - Doctor of Economics degree (table 2).

Experts were selected from four groups to provide an objective assessment of the level of CSR at NNEGC Energoatom and present various stakeholders' views.

Table 2. Group of experts

\begin{tabular}{|c|c|c|c|}
\hline $\begin{array}{l}\text { Group of } \\
\text { experts }\end{array}$ & Work position & Education level & $\begin{array}{c}\text { Work } \\
\text { experience in } \\
\text { nuclear field } \\
\text { (years) }\end{array}$ \\
\hline \multirow{3}{*}{ Scientists } & $\begin{array}{l}\text { Senior scientific expert, IEF UNAS, } \\
\text { NTUU "KPI" }\end{array}$ & higher education, $\mathrm{PhD}$ degree & 22 \\
\hline & $\begin{array}{l}\text { Scientific expert, Institute of } \\
\text { Industrial Economics, National } \\
\text { Academy of Sciences of Ukraine }\end{array}$ & $\begin{array}{l}\text { higher education, Doctor of } \\
\text { Economics }\end{array}$ & 24 \\
\hline & $\begin{array}{l}\text { Scientific expert, Taras Shevchenko } \\
\text { National University }\end{array}$ & $\begin{array}{l}\text { higher education, Doctor of } \\
\text { Economics }\end{array}$ & 15 \\
\hline \multirow{5}{*}{$\begin{array}{l}\text { Energy } \\
\text { concultants and } \\
\text { specialists }\end{array}$} & $\begin{array}{l}\text { Director of the European-Ukrainian } \\
\text { Energy agencies }\end{array}$ & higher education, $\mathrm{PhD}$ degree & 5 \\
\hline & $\begin{array}{l}\text { Senior Specialist of the National } \\
\text { Commission for Energy Regulation } \\
\text { (NKREKP) }\end{array}$ & higher economic education & 6 \\
\hline & $\begin{array}{l}\text { Communication manager of the } \\
\text { Association of Energy Suppliers }\end{array}$ & higher economic education & 6 \\
\hline & Manager of KPMG & higher economic education & 13 \\
\hline & Senior consultant of KPMG & $\begin{array}{l}\text { higher economic education, } \\
\text { Masters of Law, PhD degree }\end{array}$ & 5 \\
\hline \multirow{2}{*}{$\begin{array}{l}\text { Analysts of the } \\
\text { analytical center } \\
\text { Dixi group }\end{array}$} & $\begin{array}{l}\text { Analyst of the Dixi group, expert of the } \\
\text { analytical department of the Office of } \\
\text { the President of Ukraine }\end{array}$ & higher education & 5 \\
\hline & Data analyst of the Dixi group & Masters in Social Statistics & 6 \\
\hline $\begin{array}{c}\text { Employees of } \\
\text { separate }\end{array}$ & Manager of SS "Rivne NPP" & higher education & 14 \\
\hline
\end{tabular}


\begin{tabular}{c|l|c|}
$\begin{array}{c}\text { divisions of } \\
\text { NNEGC } \\
\text { Energoatom" }\end{array}$ & $\begin{array}{l}\text { Operator of the chemical department } \\
\text { of Khmelnytskyi Nuclear Power Plant } \\
\text { (KhNPP) }\end{array}$ & higher engineering education \\
\hline
\end{tabular}

Source: Authors' own research

The table 3 was developed based on the analysis of information from open sources (the company's website, annual reports, non-financial reporting, Code of Corporate Ethics, Labor Contract NNEGC "Energoatom", magazine "Energoatom", official document of Ministry of Energy and Environmental Protection, analytical materials of Dixi group etc) and expert assessments.

\section{Results of evaluation of the level of CSR at NNEGC «Energoatom»}

Everyone knows about Chernobyl disaster, accident in 1986 at the Chernobyl nuclear power station. It is considered the worst nuclear disaster in history of nuclear power generation. The Chernobyl disaster has a negative impact on people's attitudes to nuclear energy and corporate social responsibility of nuclear energy producers. According to the all-Ukrainian survey, 54\% hold on opinion that receiving cheap electricity from NPPs does not justify the risks that stand behind the nuclear energy sector (National Ecological Centre of Ukraine, 2015).

Chornobyl NPP officially stopped generation of electricity on 15th of December, 2000. NPP was removed from the Energoatom and re-organised in the state specialised company. At the present time the quantity of employees is less than 2400 persons. The Interim Spent Nuclear Fuel Dry Storage Facility (ISF-2) is being constructed at NPP. The construction began in 2001 and is funded from the Nuclear Safety Account of the European Bank for Reconstruction and Development (EBRD).

In recent years, the 'Chernobyl Exclusion Zone' (the area around the exploded Chernobyl reactor) has become quite popular among tourists. According to the official information, the number of tourists for the last 5 years increased more than 7 times $(16,3$ thousand in 2015 and more than 120 thousand in 2019) (State Agency of Ukraine on exclusion zone management, 2019). Last year president of Ukraine Volodymyr Zelenskyy signed a Decree "On certain issues of the development of territories affected by radioactive contamination as a result of the Chernobyl disaster". The document envisages, in particular, the development and adoption of the Chernobyl Development Strategy as a tourist attraction (The Presidential Office of Ukraine, 2019).

Today the functioning of nuclear energy is ensured by the State Enterprise "National Nuclear Energy Generating Company “Energoatom". The Company operates four nuclear power plants with 15 power units. Four nuclear power plants - Zaporizhzhya, Rivne, South-Ukraine, Khmelnytsky are separate subdivisions of "NNEGC "Energoatom". Zaporizhzhia NPP is the largest nuclear power plant not only in Ukraine, but also in Europe. The plant generates almost $47 \%$ of electricity generated by Ukrainian NPPs. The electric power produced by South-Ukraine NPP is sufficient to provide with normal conditions of life activity more than 5 million of people (NNEC "Energoatom", 2020).

Main mission of NNEGC "Energoatom" - safe manufacture of electricity. The high level of CSR is one of the basic goals of the company's strategic development.

We expertly assessed 23 indicators in six areas (Remuneration and staff motivation Indicators 1, 2, 3, 4; Staff development - Indicators 5, 6, 7, 8, 9; Safety and working conditions - Indicators 10, 11, 12, 13; Corporate culture - Indicators 14, 15, 16, 17; Comprehensive employee benefits package - Indicators 18, 19, 20, 21; Supporting young professionals Indicators 22, 23.) to highlight the CSR of NNEGC "Energoatom" by the method of SPACE analysis (Table 3). We and other scientists have selected the most relevant indicators to reflect the situation in each area. The indicators were selected among available in Energoatom's NNEGC report. 
Table 3 Performance level of CSR at "Energoatom"

\begin{tabular}{|c|c|}
\hline Indicator & Description \\
\hline $\begin{array}{l}\text { 1. Salary scale for } \\
\text { employees }\end{array}$ & $\begin{array}{l}\text { In } 2019 \text {, the average monthly salary at NNEGC Energoatom was over UAH } \\
23,800 \text {. This level is higher than in industry, but remains low for industrial } \\
\text { personnel in comparison with foreign energy enterprises. }\end{array}$ \\
\hline $\begin{array}{l}\text { 2. Dynamics of wage } \\
\text { growth }\end{array}$ & $\begin{array}{l}\text { In } 2017-2018 \text {, the salary fund of employees of NNEGC Energoatom, which is } \\
\text { included in the tariffs for electricity and heat of NPPs, was increased by UAH } \\
1.86 \text { billion or } 36 \% \text {. In } 2019 \text {, the average salary compared to } 2018 \text { increased } \\
\text { by } 35.5 \% \text {. Since } 2015 \text {, the salary fund of NNEGC Energoatom has increased } \\
\text { by } 76 \% \text {. }\end{array}$ \\
\hline $\begin{array}{l}\text { 3. Perks fee and } \\
\text { allowances }\end{array}$ & $\begin{array}{l}\text { Additional payment of employees in all subdivisions and enterprises under } \\
\text { the umbrella of Energoatom are in line of social benefits and guarantees } \\
\text { provided for by the laws of Ukraine and the collective bargaining agreement. } \\
\text { Company collective agreement provides } 29 \text { types of perks fee and } \\
\text { allowances, } 6 \text { types of bonuses. Most of the additional payment are regulated } \\
\text { by national law. }\end{array}$ \\
\hline 4. Intangible motivation & $\begin{array}{l}\text { Intangible motivation includes honors and awards. In particular, a letter of } \\
\text { thanks for personal contribution to the implementation of planned tasks, a } \\
\text { badge "Excellent Atomic Energy", a badge "Honorary Worker of Atomic } \\
\text { Energy", a badge "Honored Worker of Atomic Energy". The company also } \\
\text { celebrates the winners of professional skills competitions. }\end{array}$ \\
\hline $\begin{array}{l}\text { 5. Trainings and } \\
\text { professional courses }\end{array}$ & $\begin{array}{l}\text { Energoatom's personnel are trained in special training centers, which have } \\
\text { government licenses for such activities. In } 2019,73 \text { events were held to } \\
\text { teach anti-corruption policies and methods. During } 2017-2019 \text {, staff training } \\
\text { costs increased almost } 4 \text { times. In } 2019,96,833 \text { people-courses were made } \\
(95,125 \text { - in 2018), while the plan was } 76,529 \text { people-courses. In addition, } \\
\text { the Company conducts training for employees to develop decision-making } \\
\text { and teamwork skills and control staff qualification. }\end{array}$ \\
\hline $\begin{array}{l}\text { 6. Collaboration with } \\
\text { profile universities }\end{array}$ & $\begin{array}{l}\text { Energoatom has been cooperating with Ukrainian higher education } \\
\text { institutions under tripartite agreements. Energoatom has signed such } \\
\text { agreements with the National Technical University of Ukraine "Kyiv } \\
\text { Polytechnic Institute", Odessa National Polytechnic University, Sevastopol } \\
\text { National University of Nuclear Power and Industry. In 2018, Energoatom } \\
\text { employed } 115 \text { graduates trained in specialised universities under tripartite } \\
\text { agreements. }\end{array}$ \\
\hline $\begin{array}{l}\text { 7. Exchange of } \\
\text { experience with } \\
\text { foreign partners }\end{array}$ & $\begin{array}{l}\text { Energoatom actively cooperates with international organisations and } \\
\text { initiatives: WNA, IAEA, ENISS, IFNEC, FORATOM (through membership in } \\
\text { UNF), Energy Community, Nuclear Law Committee NEA/OECD, European } \\
\text { Bank for Reconstruction and Development, etc. This allows employees to } \\
\text { gain new experience, exchange ideas, discuss important projects, integrate } \\
\text { into the European scientific community. }\end{array}$ \\
\hline $\begin{array}{l}\text { 8. Formation of } \\
\text { personnel reserve }\end{array}$ & $\begin{array}{l}\text { The company has introduced a system of training personnel reserve of } \\
\text { managers. Its purpose is the development and deepening of managerial } \\
\text { competencies of specialists and training of middle and senior managers. The } \\
\text { training program is designed for two years. Provides participation in events, } \\
\text { attending various meetings, internships in management positions at the } \\
\text { power plant, learning English. }\end{array}$ \\
\hline $\begin{array}{l}\text { 9. Improving working } \\
\text { conditions }\end{array}$ & $\begin{array}{l}\text { Energoatom focus on creating equal employment opportunities, prevent } \\
\text { discrimination at workplaces, provide good and flexible working conditions } \\
\text { for workers with family responsibilities and ensure gender equality at } \\
\text { workplace. In } 2019 \text {, the Company's expenses on improve working conditions } \\
\text { increased by } 10 \% \text { year-on-year. Energoatom has successfully completed the } \\
\text { compliance audits against the requirements of OHSAS 18001:2007 "Health } \\
\text { and Safety Management System. Requirements". }\end{array}$ \\
\hline $\begin{array}{l}\text { 10. Conducting safety } \\
\text { training }\end{array}$ & $\begin{array}{l}\text { The Health and Safety training for employees is designed to create proper, } \\
\text { safe and healthy working conditions, prevent accidents and occupational } \\
\text { diseases, and protect the health of workers during operation of equipment. } \\
\text { In 2016, special courses on performance of high-risk work at Energoatom }\end{array}$ \\
\hline
\end{tabular}

Vol. 16, No. 2,pp. 152-166, ISSN 2069-8887| Management \& Marketing. Challenges for the Knowledge Society 


\begin{tabular}{|c|c|}
\hline & $\begin{array}{l}\text { amounted to } 47,082 \text { man-courses, and the figure reached } 48,924 \text { man- } \\
\text { courses in } 2017 \text {. In } 2019 \text {, NPPs held } 265 \text { facility training sessions including } \\
\text { the firefighting drills with engagement of firefighting squads. They were } \\
\text { attended by } 8,788 \text { people. Every two years Energoatom organises the } \\
\text { International Scientific and Practical Conference on the Safety and Security } \\
\text { Culture at NPPs. }\end{array}$ \\
\hline $\begin{array}{l}\text { 11. Occupational injuries } \\
\text { and occupational } \\
\text { diseases }\end{array}$ & $\begin{array}{l}\text { Energoatom regularly takes actions to prevent occupational injuries and } \\
\text { occupational diseases, as well as to detect, assess and minimise occupational } \\
\text { risks. These are collective boards that coordinate activities of nuclear power } \\
\text { plants' subdivisions in fostering and enhancing the safety culture of the } \\
\text { personnel. In 2017, no occupational diseases, accidents, group accidents and } \\
\text { fatal work-related accidents were registered at Energoatom. The Company } \\
\text { registered four work-related accidents, in } 2019 \text { - } 7 \text { accidents. }\end{array}$ \\
\hline $\begin{array}{l}\text { 12. Providing staff with } \\
\text { modern technical } \\
\text { facilities }\end{array}$ & $\begin{array}{l}\text { The company spent } 260 \text { million UAH to ensure the implementation of fire } \\
\text { protection measures (including firefighting drills for employees) in the } \\
\text { previous year. Employees are provided with technical means in accordance } \\
\text { with the law and internal programs. }\end{array}$ \\
\hline $\begin{array}{l}\text { 13. Decommissioning of } \\
\text { potentially hazardous } \\
\text { equipment }\end{array}$ & $\begin{array}{l}\text { Safety of power units of Ukrainian NPPs is being constantly increased } \\
\text { through the implementation of the respective safety enhancement } \\
\text { programmers developed for a specified period. In 2017, the Company } \\
\text { completed the development and implementation of the guidelines for severe } \\
\text { accidents management at all NPPs. Energoatom implemented about } 150 \\
\text { measures within the framework of the Complex (Consolidated) Safety } \\
\text { Upgrade Programme of Power Units of Ukrainian NPPs in 2018. Out of these, } \\
46 \text { actions include procurement of the equipment at the expense of credit } \\
\text { funds. At the same time, in 2019, the service life of } 15 \text { power units were } \\
\text { extended. }\end{array}$ \\
\hline 14. Corporate Ethics & $\begin{array}{l}\text { The Code of Corporate Ethics (hereinafter referred to as the Code) has been } \\
\text { in place at Energoatom since } 2010 \text {. It defines the principles of ethics and } \\
\text { rules of conduct for employees at work. In addition to the code of corporate } \\
\text { ethics, the document "Compliance Policy" was approved. In 2017, the policy } \\
\text { was implemented during public procurements, production and any other } \\
\text { operations of the Company. }\end{array}$ \\
\hline 15. Teamwork & $\begin{array}{l}\text { The Company practices project work, which ensures the creation of teams } \\
\text { and working groups. There are also competitions between teams for the best } \\
\text { idea or technical solution. }\end{array}$ \\
\hline $\begin{array}{l}\text { 16. Social psychological } \\
\text { climate and internal } \\
\text { image of enterprise }\end{array}$ & $\begin{array}{l}\text { The company constantly conducts internal audits, motivating trainings, } \\
\text { organizes joint cultural and health events, creates new channels of } \\
\text { communication with employees. The company recognizes leadership as the } \\
\text { ability to make decisions at all levels of activity, adheres to the principles of } \\
\text { gender equality, values initiative. }\end{array}$ \\
\hline $\begin{array}{l}\text { 17. Internal } \\
\text { communications and } \\
\text { feedback system }\end{array}$ & $\begin{array}{l}\text { The Company has introduced the following mechanisms to obtain feedback } \\
\text { from the personnel: regular questionnaires and social surveys, receipt of } \\
\text { requests, inquiries and submissions via dedicated sections of the Company } \\
\text { and production enterprises' web-sites. Specifically, features "Ask a question" } \\
\text { in sections "Safety Culture" and "Procurement", feature "Trust Box" (for anti- } \\
\text { corruption issues). Employees can also submit direct proposals to the } \\
\text { management via such trust boxes and dedicated sections "Proposals to the } \\
\text { Management" on NPPs' intranets (for registered users) or to submit written } \\
\text { or oral proposals or appeals (submissions, claims, petitions) to the name of } \\
\text { the Company's or separated subdivisions' management. }\end{array}$ \\
\hline $\begin{array}{l}\text { 18. Development of social } \\
\text { infrastructure }\end{array}$ & $\begin{array}{l}2.5 \text { million UAH were spent on capital investments in housing construction } \\
\text { in } 2019 \text {. For comparison: in } 2018 \text { - UAH } 1.2 \text { million. More than } 20 \text { social } \\
\text { infrastructure facilities are included in the integral property complex of } \\
\text { NNEGC Energoatom. These facilities include spas, health facilities, sports } \\
\text { complexes, etc. }\end{array}$ \\
\hline 19. Medical insurance & $\begin{array}{l}\text { According to the "On Insurance" Law, several types of compulsory insurance } \\
\text { are provided by Energoatom. The Collective Agreement also provides } \\
\text { individual insurance of emergency crews members. } 8.8 \text { million UAH invested }\end{array}$ \\
\hline
\end{tabular}




\begin{tabular}{|c|l|}
\hline & $\begin{array}{l}\text { by ENERGOATOM in medical check-ups of employees in 2018. 27,586 } \\
\text { employees had medical check-ups in 2018. }\end{array}$ \\
\hline $\begin{array}{l}\text { 20. Workers } \\
\text { rehabilitation }\end{array}$ & $\begin{array}{l}\text { Company's employees annually have the opportunity to improve their health } \\
\text { in recreational facilities. In 2019, 18 077 employees took advantage of these } \\
\text { services (in 2016, 14,227). The Company takes care of the children of its } \\
\text { employees as well: UAH 51.09 million were invested into rehabilitation of 7 } \\
\text { 170 children (in 2016, 5 467 children). }\end{array}$ \\
\hline \multirow{5}{*}{$\begin{array}{l}\text { 21. Workers } \\
\text { compensation } \\
\text { health and safety programmes, provision of housing, and training } \\
\text { programmes: various types of welfare assistance (including birth allowance, } \\
\text { nursing aid for employees with children aged from 3 to 6 years), one-off } \\
\text { recreation allowance, one-off retirement allowance, interest-free loans to } \\
\text { improve housing conditions and student loans, employee commuting } \\
\text { services paid by employers, assistance to the WWII veterans and combatants } \\
\text { involved in the counter-terrorism operations (ATO). }\end{array}$} \\
\hline $\begin{array}{l}\text { 22. Unleashing young } \\
\text { employees creativity } \\
\text { and innovation }\end{array}$ & $\begin{array}{l}\text { Energoatom conducts annual competitions of professional skills among the } \\
\text { young professionals under 35, which makes it possible to identify the best } \\
\text { employees. According to the terms and conditions of such competitions, } \\
\text { winners receive a bonus, an improvement in rank or category and a 10\% } \\
\text { monthly salary mark-up for qualifications. }\end{array}$ \\
\hline \multirow{2}{*}{$\begin{array}{l}\text { 23. Adaptation of young } \\
\text { professionals }\end{array}$} & $\begin{array}{l}\text { Energoatom reserves jobs to employ young professionals, both women and } \\
\text { men, and applies the parity of participation in making production, economic, } \\
\text { social and managerial decisions. The collective agreement and various } \\
\text { development programs provide for compensation and training for young } \\
\text { professionals. Production rates for young workers have been reduced by } \\
\text { 20\%. In 2020, according to the STUD-POINT Center for Career Development, } \\
\text { NNEGC Energoatom was recognized as one of the twenty-five best Ukrainian } \\
\text { companies based on openness to young talents. }\end{array}$ \\
\hline
\end{tabular}

Ukraine -2035)

Source: (NNEC “Energoatom”; DiXi Group; Oliinyk, 2017; Bilan et al., 2019; Energy strategy of

According to all indicators of internal social responsibility, NNEGC Energoatom is estimated at 2-3 points. As a whole, 34,736 employees worked for Energoatom in 2019 (NNEC "Energoatom"). The Company operates with due account for the principles of gender equality, creates safe jobs and prevents any discrimination at the workplace. Relations with employees are based on the social partnership principles. During 2017-2019, the system of staff training and retraining was improved. The cost of staff training in 2019 was UAH 130 million, which is 3 times higher than in 2017 (NNEGC "Energoatom", 2019). Energoatom seeks to pay competitive remuneration to its employees, places a strong focus on new and existing motivation tools to achieve high performance, and creates good conditions for work, professional and personal development.

However, some areas of internal social responsibility need more attention and funding. In particular, increasing the specialists' salaries, improving working conditions, ensuring the rehabilitation of more employees. This is partly due to the fact that in 2016-2019, NNEGC Energoatom had one of the lowest tariffs in the world for the supply of electricity generated at nuclear power plants, as well as the lowest tariff in Ukraine among all types of generation. This factor influences of the financial capacity of the enterprise.

Experts provided a rating for indicators, and identified the concordance coefficients to measure the agreement among rating. We calculated the average rating for each of the indicators, multiplied by the coefficient and determined the total value for each direction of evaluation. Then we calculated the general index of internal social responsibility assessment for NNEGC "Energoatom" in 2016 - 2020 (Table 4).

Table 4 The system of indicators for assessing internal social responsibility and their significance for NNEGC Energoatom (2016-2020). 


\begin{tabular}{|c|c|c|c|c|}
\hline Direction of evaluation & Indicator & Rating & Coefficient & Value \\
\hline \multirow{4}{*}{$\begin{array}{l}\text { Remuneration and staff } \\
\text { motivation }\end{array}$} & Salary level for employees & 2 & 0,3 & 0,6 \\
\hline & Dynamics of wage growth & 3 & 0,3 & 0,9 \\
\hline & Intangible motivation & 2 & 0,2 & 0,4 \\
\hline & Perks fee and allowances & 2 & 0,2 & 0,4 \\
\hline Totally & & & 1 & 2,3 \\
\hline \multirow{6}{*}{ Staff development } & Improving working conditions & 2 & 0,2 & 0,4 \\
\hline & Trainings and professional courses & 3 & 0,20 & 0,6 \\
\hline & Collaboration with profile universities & 3 & 0,10 & 0,3 \\
\hline & $\begin{array}{l}\text { Exchange of experience with foreign } \\
\text { partners }\end{array}$ & 3 & 0,25 & 0,75 \\
\hline & Formation of personnel reserve & 3 & 0,25 & 0,75 \\
\hline & & & & 2,8 \\
\hline \multirow{4}{*}{$\begin{array}{l}\text { Safety and working } \\
\text { conditions }\end{array}$} & Conducting safety training & 3 & 0,25 & 0,75 \\
\hline & $\begin{array}{l}\text { Occupational injuries and occupational } \\
\text { diseases }\end{array}$ & 2 & 0,25 & 0,5 \\
\hline & $\begin{array}{l}\text { Providing staff with modern technical } \\
\text { facilities }\end{array}$ & 3 & 0,25 & 0,75 \\
\hline & $\begin{array}{l}\text { Decommissioning of potentially } \\
\text { hazardous equipment }\end{array}$ & 2 & 0,25 & 0,5 \\
\hline Totally & & & 1 & 2,5 \\
\hline \multirow{5}{*}{ Corporate culture } & Corporate Ethics & 3 & 0,20 & 0,6 \\
\hline & Teamwork & 3 & 0,30 & 0,9 \\
\hline & $\begin{array}{l}\text { Social psychological climate and internal } \\
\text { image of enterprise }\end{array}$ & 3 & 0,30 & 0,9 \\
\hline & $\begin{array}{l}\text { Internal communications and feedback } \\
\text { system }\end{array}$ & 2 & 0,20 & 0,4 \\
\hline & & & 1 & 2,8 \\
\hline \multirow{5}{*}{$\begin{array}{l}\text { Comprehensive employee } \\
\text { benefits package }\end{array}$} & Development of social infrastructure & 2 & 0,20 & 0,4 \\
\hline & Medical insurance & 3 & 0,30 & 0,9 \\
\hline & Workers rehabilitation & 2 & 0,30 & 0,6 \\
\hline & Workers compensations & 3 & 0,20 & 0,6 \\
\hline & & & 1 & 2,5 \\
\hline \multirow{2}{*}{$\begin{array}{l}\text { Supporting young } \\
\text { professionals }\end{array}$} & $\begin{array}{l}\text { Unleashing young employees creativity } \\
\text { and innovation }\end{array}$ & 3 & 0,5 & 1,5 \\
\hline & Adaptation of young professionals & 3 & 0,5 & 1,5 \\
\hline Totally & & & 1 & 3,0 \\
\hline
\end{tabular}

Source: Authors' own research

We compared the sum of points for Energoatom with the maximum possible points for individual groups of factors (Table 5).

Table 5 The ratio of the actual number of points to the maximum possible

\begin{tabular}{|c|c|c|c|}
\hline Group of factors & Actual score & $\begin{array}{c}\text { Maximum possible } \\
\text { score }\end{array}$ & \% of possible score \\
\hline $\begin{array}{c}\text { Factors of financial stability of the } \\
\text { enterprise }\end{array}$ & 2,3 & 3 & 68 \\
\hline $\begin{array}{c}\text { Factors of functional safety of the } \\
\text { enterprise }\end{array}$ & 2,5 & 3 & 83 \\
\hline $\begin{array}{c}\text { Factors of competitiveness of the } \\
\text { enterprise }\end{array}$ & 5,3 & 6 & 88 \\
\hline
\end{tabular}




\begin{tabular}{|c|c|c|c|}
\hline $\begin{array}{c}\text { Factors of attractiveness of the } \\
\text { enterprise }\end{array}$ & 5,8 & 6 & 97 \\
\hline Total & 15,9 & 18 & 88 \\
\hline
\end{tabular}

The quadrilateral is constructed by combining the values of each group of factors (Fig. 1). The SPACE analysis matrix shows that the financial situation factor has the lowest percentage of the maximum possible number of points.

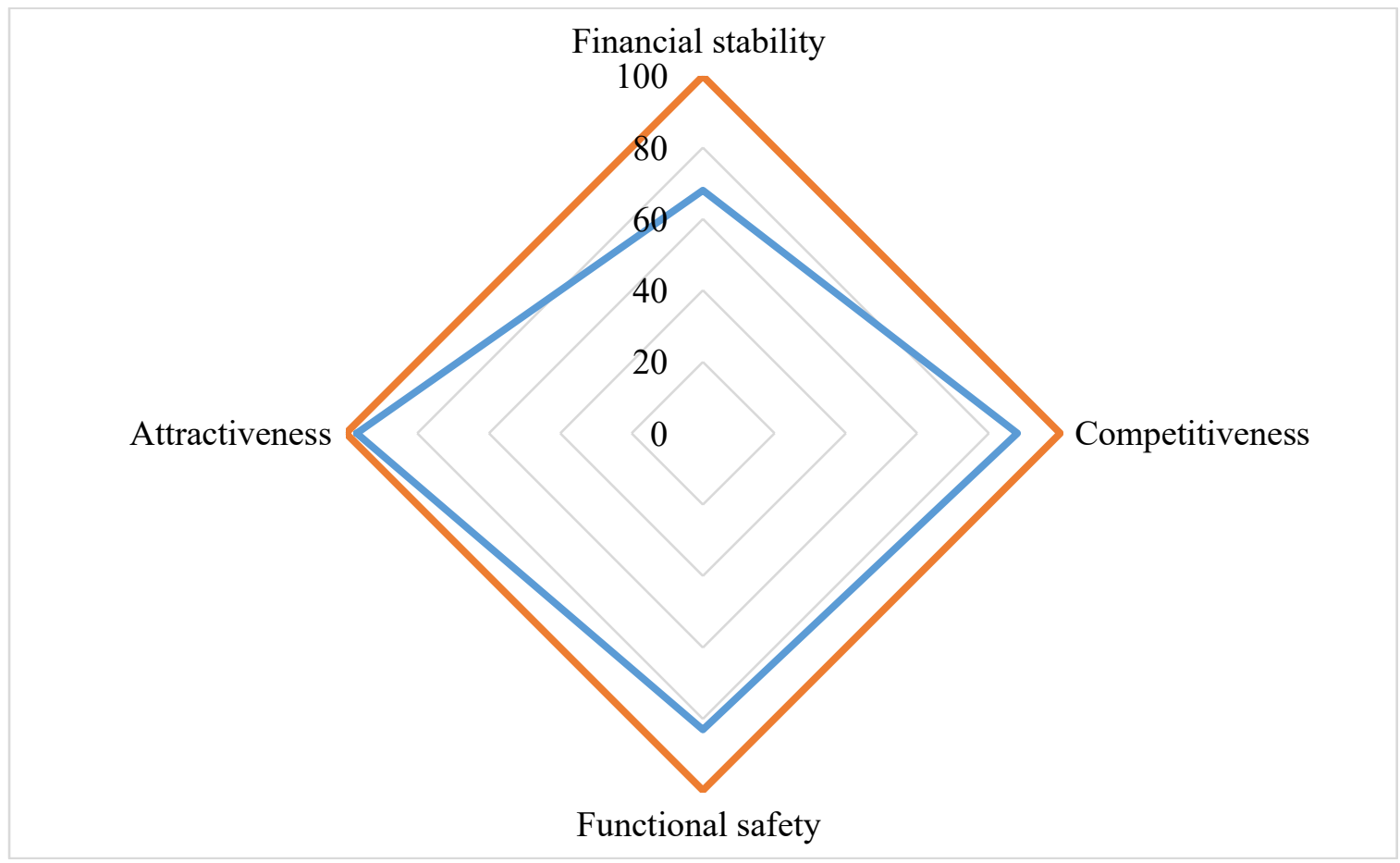

Fig. 1 Energoatom's strategic position (SPACE - analysis matrix)

Source: Authors' own research

The general index of internal social responsibility of NNEGC Energoatom is 88\%, which indicates a high level of responsibility of the enterprise. However, it should be noted that increasing financial attractiveness is a reserve for improving social responsibility in the enterprise.

We determine the type of strategy of enterprise internal social responsibility based on the construction of a coordinate system:

$$
\begin{aligned}
& X=F A-F C=5,8-5,3=0,3 \\
& y=F F-F S=2,3-2,5=-0,2
\end{aligned}
$$

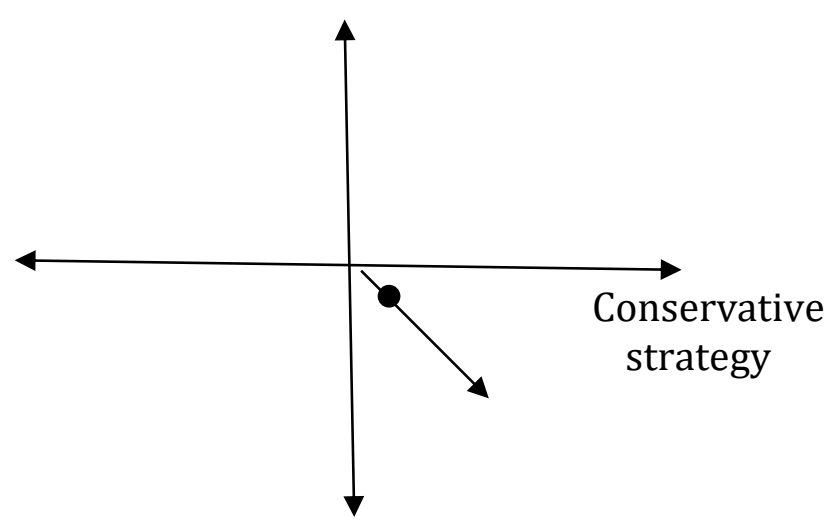

Fig. 2 Energoatom's internal social responsibility strategy 
Fig. 2 illustrates that a competitive type is an optimal personnel management strategy for the enterprise. The factors of "financial condition" and "competitive advantages" have become "Weaknesses" of internal social responsibility. First of all, it involves raising wages, expanding the compensation package for employees, ensuring safe working conditions. NNEGC Energoatom is a monopolist in nuclear electricity production, but as an employer, the enterprise operates in a competitive market. Low wages encourage highly qualified professionals to look for a different job in the energy sector or to realize their potential abroad.

Internal responsibility evaluation in NNEDC Energoatom by using the SPACE-analysis determines a high level of responsibility at the enterprise. The integrated indicator for four groups of indicators is $88 \%$ of $100 \%$ possible. The highest score in the "attractiveness of the enterprise" group of factors is 5.8 out of $6(97 \%)$, the lowest one is the financial stability of the enterprise. Accordingly, this area needs special attention. In particular, the reserves for improving social responsibility are changing the system of remuneration, strengthening the motivational component, and improving the compensation package.

\section{Conclusions}

Nuclear energy still makes a significant contribution to economic development in the world. In the case of limited energy resources, environmental problems, high oil and gas prices, nuclear power might become even more important in the future. The social component has a significant impact on the competitiveness of nuclear energy sector. One of the key aspects of the transition to a socially-oriented economy is the implementation of CSR initiatives and preparing CSR development strategies for enterprises, especially in such sensitive sectors as nuclear energy. The CSR development of nuclear energy is an important factor in strengthening Ukraine's energy security, ensuring the well-being of the NPP satellite communities, and enhancing the competitiveness of the national economy.

The evaluation of the CSR level in NNEGC Energoatom indicates a high level of CSR. Priority areas of CSR are providing training and staff development, adaptation of young professionals, improving working conditions.

Despite the high level of CSR inthe enterprise, some issues of nuclear energy operation need special attention. In particular, the reserves for improving social policy are ensuring a competitive salary, increasing the level of occupational safety, improving the internal communication system.

It should be emphasized that Ukrainian scientists have not analysed the social responsibility of nuclear energy sufficiently. Most research is related to the analysis of production capacity and economic efficiency of Energoatom. This paper is the first scientific research on the social responsibility of nuclear energy.

The theoretical contribution of the study is the modification of the classical method of SPACE-analysis, the formation of a system of factors and relevant indicators to evaluate the level of social responsibility. The modified method can be used not only for individual enterprises, but also for entire sectors of economy. A practical contribution is identified in the analysis of the strengths and weaknesses of NNEGC Energoatom social responsibility and the formation of reserves to improve the social responsibility of the enterprise.

Limitations of the results:

Nuclear energy is a closed, non-public industry

$\checkmark$ Difficulty in ting access to most data

$\checkmark$ Lack of previous research on social responsibility of nuclear energy producers

$\checkmark$ "Energoatom" has been publishing non-financial reports for only four years Vol. 16, No. 2, pp. 152-166, ISSN 2069-8887| Management \& Marketing. Challenges for the Knowledge Society 
Despite the difficulties of data collection, the objectives of the research were achieved. The article is devoted to the analysis of the internal social responsibility of the enterprise. Areas of further research will include evaluating NNEGC Energoatom's external social responsibility and analysing the correlation between a high CSR level at the enterprise and its operational efficiency in the nuclear energy sector.

\section{References}

Banerjee, S. B., \& Bonnefous, A. M. (2011). Stakeholder management and sustainability strategies in the French nuclear industry. Business Strategy and the Environment, 20(2), 124-140

Bilan, Y., Mishchuk, H., Samoliuk, N., \& Grishnova, O. (2019). ICT And Economic Growth: Links And Possibilities Of Engaging. Intellectual Economics, 13(1).

Borocki, J., Radisic, M., Stefanic I. (2018). SPACE Analysis as a Tool for Internal Development Factors Measurement within Companies. Technical Gazette 25, 404-410

Cai, Y., Jo, H., \& Pan, C. (2012). Doing well while doing bad? CSR in controversial industry sectors. Journal of Business Ethics, 108(4), 467-480.

Chena, Y., Puyan Nieb, P., \& Wang, C. (2019). Effects of corporate social responsibility considering emission restrictions. Energy strategy reviews, 121-131

Crane, A., Palazzo, G., Spence, L. J., \& Matten, D. (2014). Contesting the Value of "Creating Shared Value". California Management Review, 56(2).

Devers, C., E. Dewett, T., Mishina, Y. Belsito, C. A. (2009). A General Theory of Organizational Stigma, Organization Science, 20(1), 154-171.

Dima, A.M., Ghinea, V. M. (2016). A model of Academic Leadership, Conference: 12th European Conference on Management, Leadership and Governance (ECMLG) Location: Natl Univ Polit Studies \& Publ Adm, Coll Management, Bucharest, ROMANIA. Proceedings of the Conference on European Management Leadership and Governance, pp. 61-70 .

Dima, A.M., Țuclea, C.E., Vrânceanu, D.M., Țigu, G. (2019). Sustainable Social and Individual Implications of Telework: A New Insight into the Romanian Labor Market.

Sustainability, 11, 3506. https://doi.org/10.3390/su11133506.

Dimitrova, T., V. (2017). Evaluating the strategic position of an organisation through SPACE analysis. Economic archive, 19-32.

DiXi Group. http://dixigroup.org/about/

Gennaioli, C., \& Tavoni, M. (2016). Clean or dirty energy: Evidence of corruption in the renewable energy sector. Public Choice, 166, 261-290.

Goodfellow, M. J., Dewick, P., Wortley, J., \& Azapagic, A. (2015). Public perceptions of design options for new nuclear plants in the UK. Process Safety and Environmental Protection, 94, 72- 88. doi: 10.1016/j.psep.2014.12.008.

Grishnova, O. A., \& Kostenko, T. O. (2014). Information technologies within the system of novel factors of labour productivity growth: trends and paradoxes. Aktual'ni Problemy Ekonomiky= Actual Problems in Economics, (152), 462.

Grishnova, O. A, Mischuk, G. Y. \& Oliynyk, O. 0. (2014). Social responsibility in labor relations: monograph. NUVGP, Rivne, Ukraine, 216.

Grougiou, V., Dedoulis, E., \& Leventis, S. (2016). Corporate Social Responsibility Reporting and Organizational Stigma: The Case of "Sin" Industries, Journal of Business Research, 69(2), 905-914

Hahn, T., Figge, F., Pinkse, J., \& Preuss, L. (2010). Trade-offs in corporate sustainability: you can't have your cake and eat it. Business Strategy and the Environment, 19(4), 217229.

Hegerty, S. W. (2019). Commodity prices, credit cycles, and consumption in Russia, Ukraine, and Belarus. Journal of International Studies, 12(2), 9-21. doi:10.14254/2071$8330.2019 / 12-2 / 1$ 
Husted, B. W., \& Allen, D. B. (2009). Strategic corporate social responsibility and value creation. Management international review, 49(6), 781-799.

Husted, B. W., \& Allen, D. B. (2011). Corporate Social Strategy: Stakeholder Engagement and Competitive Advantage. Cambridge: Cambridge University Press

Institute of Social and Ethical Account Ability. http://www.accountability.org/

International Energy Forum «Open energy week 2017». http://www.energoatom.com.ua/ua/press_centr-19/presentations39/p/miznarodnij_energeticnij_forum_open_energy_week_2017-4387

Kato, T., Takahara, S., Nishikawa, M., \& Homma, T. (2013). A case study of economic incentives and local citizens' attitudes toward hosting a nuclear power plant in Japan: Impacts of the Fukushima accident. Energy Policy, 59, 808-818. doi: 10.1016/j.enpol.2013.04.043

Khlevytska, T. B. (2014). Methodical approach to the assessment of corporate social activities effectiveness at the enterprises on the integrative platform. Economic Development Strategy for Ukraine, 34, 135-141.

Kolk, A., \& Tulder, R.V. (2010). International business, corporate social responsibility and sustainable development. Int. Bus. Rev., 19, 119-125.

Lindell, M.,K, \& Perry, R.,W. (1990). Effects of the Chernobyl accident on public perceptions of nuclear plant accident risks. Risk Anal. 10(3), 393-406. doi: 10.1111/j.15396924.1990.tb00522.x. PMID: 2236743.

Lindorff, M., Jonson, E. P., \& McGuire, L. (2012). Strategic corporate social responsibility in controversial industry sectors: The social value of harm minimisation. Journal of Business Ethics, 110(4), 457-467.

Lu, J., Ren, L., Qiao, J., Yao, S., Strielkowski, W., \& Streimikis, J. (2019). Corporate Social Responsibility and Corruption: Implications for the Sustainable Energy Sector. Sustainability, 11, 4128.

Ministry of energy and environment protection of Ukraine. http://mpe.kmu.gov.ua/minugol/control/uk/publish/article?art_id=245188609\&cat_id=24 5070636

Mishchuk, H., \& Grishnova, O. (2015). Empirical study of the comfort of living and working environment-Ukraine and Europe: comparative assessment. Journal of International Studies, 8, $67-80$.

Mishchuk, H., Samoliuk, N., \& Bilan, Y. (2019). Measuring social justice in the light of effectiveness of public distributive policy. Administration \& Public Management Review, (32), 63-76.

Mizuo, J. (2008). The social responsibility of nuclear energy. Progress in Nuclear Energy, 50(2),,694-699. https://doi.org/10.1016/j.pnucene.2007.11.075.

Myšková, R., \& Hájek, P. (2019). Relationship between corporate social responsibility in corporate annual reports and financial performance of the US companies. Journal of International Studies, 12(1), 269-282. doi:10.14254/2071-8330.2019/12-1/18

National Ecological Centre of Ukraine (2015) «Attitudes of Ukrainians toward nuclear energy national ecological centre of Ukraine». http://necu.org.ua/stavlennya-naselennyaukrayiny-do-atomnoyi-enerhetyky/

National Energy and Utilities Regulatory Commission

(NEURC). http://www.nerc.gov.ua/?id=118

Naveen Singhal, \& Arun Dev (2016) Global Reporting Initiative; Sustainability Reporting. Conf. on Technology and Operation of Offshore Support Vessels (OSV Singapore), 93-99

NNEGC Energoatom. : http://www.energoatom.kiev.ua/ua/

Non-financial report of NNEGC Energoatom 2019. http://www.energoatom.com.ua/uploads/2020/web_EA_19_s.pdf 
Nuclear energy institute (2019) https://www.nei.org/Knowledge-Center/NuclearStatistics/World-Statistics/Top-10-Nuclear-Generating-Countries

Oliinyk, 0. 0. (2017). Corporate social responsibility in the field of occupational safety and health. Scientific Bulletin of National Mining University, 2, 128-133

Oliveira, R., Zanella, A., \& Camanho, A. (2019). The assessment of corporate social responsibility: The construction of an industry ranking and identification of potential for improvement. European Journal of Operational Research, 2, 498-513

Pisani, N., Kourula, A., Kolk, A., \& Meijer, R. (2017). How global is international CSR research, Insights and recommendations from a systematic review. Journal of World Business. doi: https://doi.org/10.1016/j.jwb.2017.05.003

Rimsaite, L. (2019). Corruption risk mitigation in energy sector: Issues and challenges. Energy Policy, 125, 260-266.

Rudnicki, W., \& Vagner, I. (2014) Methods of strategic analysis and proposal method of measuring productivity of a company. The Małopolska School of Economics in Tarnów Research Papers Collection, 25(2), 175-184.

Sadekina, S., \& Zamana, S. (2019). Nuclear power as foundation of a clean energy future: A review. Energy Procedia, 513-518.

Shadrina, E. (2012). Fukushima fallout: gauging the change in Japanese nuclear energy policy. International Journal of Disaster Risk Science, 3(2), 69-83. doi: 10.1007/s13753-0120008-0

Simončič, M. (2019). Motivation for Social Responsibility in Nuclear Power Plants, Journal of Universal Excellence, 8(3), 232-245

Simončič, M., \& Žurga, G. (2016). Social responsible communication of nuclear power plant with external stakeholders. International Journal for Nuclear Power, 61(11), 653-659.

Simončič, M., \& Žurga, G. (2019). Successful Co-Existance of Nuclear Power Plants with Their External Stakeholders. International Journal for Nuclear Power, 64(4), 197-202.

Siqueira, D., S. (2019). Current perspectives on nuclear energy as a global climate change mitigation option. Mitigation and Adaptation Strategies for Global Change, 24 (5), 749777

Spence, D. B. (2011). Corporate social responsibility in the oil and gas industry: The importance of reputational risk. Chi. Kent L. Rev., 86, 59-85.

State Agency of Ukraine on exclusion zone management (2019), «Statistic of visiting». http://dazv.gov.ua/en/

Stjepcevic, J., \& Siksnelyte, I. (2017). Corporate Social Responsibility in Energy Sector. Transform. Bus. Econ., 16, 21-33.

Streimikiene, D., Simanaviciene, Z., \& Kovaliov, R. (2009). Corporate social responsibility for implementation of sustainable energy development in Baltic States. Renew. Sustain. Energy Rev., 13, 813-824

The Presidential Office of Ukraine (2019) «Head of State signed a decree on the development of the Chernobyl Exclusion Zone». https://www.president.gov.ua/en/news/glavaderzhavi-pidpisav-ukaz-shodo-rozvitku-chornobilskoyi-z-56321

Truelove, H. B., \& Greenberg, M. (2013). Who has become more open to nuclear power because of climate change? Climatic Change, 116, 389-409. doi: 10.1007/s10584-0120497-2

Tvaronavičienė, M., Prakapienė, D., Garškaitė-Milvydienė, K., Prakapas, R., \& Nawrot, 七. (2018). Energy Efficiency in the Long-Run in the Selected European Countries. Economics and Sociology, 11(1), 245-254. doi:10.14254/2071- 789X.2018/11-1/16

Winn, M., Pinkse, J., \& Illge, L. (2012). Case Studies on Trade-Offs in Corporate Sustainability. Corporate Social Responsibility and Environmental Management, 19(2), 63-68. 
World Nuclear Assosiation (2020). Nuclear Power in the World Today. https://www.worldnuclear.org/information-library/current-and-future-generation/nuclear-power-in-theworld-today.aspx

World Nuclear Association (2017). World Nuclear Performance Report , 32

Yakymova, L., \& Kuz, V. (2019). The use of discriminant analysis in the assessment of municipal company's financial health. Economics and Sociology, 12(2), 64-78. doi:10.14254/2071-789X.2019/12-2/4

Yates, M., \& Hollensbe, E. (2013). On the Positives of Peripheral Corporate Social Responsibility. Industrial and Organizational Psychology, 6(4), 368-372. 